\title{
Suppressor genes as molecular markers of colorectal cancer - a review of the latest reports
}

\section{Geny supresorowe jako molekularne markery raka jelita grubego - przegląd najnowszych doniesień}

\author{
Agnieszka M. Piechowska', Monika Wawszczak, Anna Cedro², Stanisław Głuszek ${ }^{1,3}$ \\ ${ }^{1}$ Department of Surgical Medicine with the Laboratory of Medical Genetics,, Institute of Medical Sciences, Jan Kochanowski University, \\ Kielce, Poland \\ Head of the Department: Prof. Stanisław Głuszek MD, PhD \\ 2Department of Cardiovascular Disease Prevention and Pharmacology, Institute of Health Sciences, Jan Kochanowski University, \\ Kielce, Poland \\ Head of the Department: Prof. Beata Wożakowska-Kapłon MD, PhD \\ ${ }^{3}$ Department of Clinic General Oncological and Endocrinological Surgery, Regional Hospital, Kielce, Poland \\ Head of the Department: Prof. Stanisław Głuszek MD, PhD
}

Key words: colorectal cancer, biomarkers, signalling pathways, suppressor genes.

Słowa kluczowe: rak jelita grubego, biomarkery, geny supresorowe, szlaki sygnałowe.

\begin{abstract}
Suppressor gene research is one of the main current trends in modern cancer research. Oncogenesis, including colorectal cancer (CRC), is a process strictly dependent on the proper functioning of the suppressor genes and their proteins. The molecular genetic studies of hereditary cases and sporadic forms of cancer conducted for several years have revealed that a significant feature of the occurrence and progression of neoplastic changes is silencing of the expression of tissue-specific suppressor genes. Restoring the proper activity of the respective suppressor proteins plays a key role in anti-cancer prevention and gives hope for the development of effective personalised therapy. This review presents the latest reports on the molecular mechanisms regulating the expression, activity, and function of suppressor genes, which were silenced in tissues and cell lines of colorectal cancer, and restoration of their correct expression inhibited the proliferation and invasion of CRC cells.
\end{abstract}

\section{Streszczenie}

Badania genów supresorowych to jeden z głównych nurtów współczesnych badań nad nowotworami. Onkogeneza, również raka jelita grubego (CRC), jest procesem ściśle uzależnionym od właściwego działania genów supresorowych i kodowanych przez nie białek. Prowadzone od lat genetyczne badania molekularne przypadków dziedzicznych oraz postaci sporadycznych nowotworów wykazały, że znamienną cechą wystąpienia i progresji zmian nowotworowych jest wyciszenie ekspresji charakterystycznych dla danej tkanki genów supresorowych, a przywrócenie właściwej aktywności odpowiednich białek supresorowych odgrywa kluczową rolę w ochronie przeciwrakowej i daje nadzieję stworzenia skutecznej spersonalizowanej terapii antynowotworowej. W niniejszym opracowaniu przedstawiono najnowsze doniesienia na temat molekularnych mechanizmów regulujących ekspresję, aktywność i funkcję genów supresorowych, których wyciszenie zaobserwowano w tkankach i liniach komórkowych raka jelita grubego, a odtworzenie ich prawidłowej ekspresji hamowało proliferację oraz inwazję komórek CRC.

\section{Introduction}

Colorectal cancer (CRC) is one of the most common cancers in the world, and its incidence has increased in recent years $[1,2]$. It is the third most common cancer in men (10\%) and the second in women (9\%). Being the second most common cancer cause of death in the world, with about 881,000 deaths estimated for 2018, it appears to be a significant epidemiological problem [2,
3]. Colorectal cancer most often develops sporadically; hereditary forms make up 10-30\% of cases. These include: Lynch syndrome - hereditary non-polyposis colorectal cancer (HNPCC), familial adenomatous polyposis (FAP), and other polyposis syndromes (PeutzJeghers syndrome, juvenile polyposis syndrome) and familial colorectal cancer (FCC).

The carcinogenesis of colorectal cancer, especially its sporadic form (sCRC), is not completely under- 
stood. The essence of this process is the formation of a cascade of cytogenetic and epigenetic changes as a result of long exposure to environmental and hereditary cancer risk factors that disrupt cellular homeostasis. The carcinogenesis process is stretched in time, about 10-20 years pass from the first mutation to the development of invasive cancer, and about 5-10 years from the appearance of the polyp to invasive cancer. The long period of cancer formation and the repeated absence of precursor changes signalling the cancer process indicate the need to search for new diagnostic markers of the disease. Recent scientific reports show that the molecular mechanism of colorectal cancer pathogenesis is more complicated and diverse than the first linear multi-stage model with the inactivation of the APC, SMAD4, and TP53 suppressor genes and the stimulation of the KRAS oncogene [4]. Present research capabilities created by next-generation sequencing enabling the screening of the entire genome in search of new genes that can be markers of CRC oncogenesis have opened up exciting new possibilities in recent years.

This article presents a review of the latest reports on previously recognised and tested, as well as new, currently proposed suppressor genes as molecular markers of colorectal cancer, with particular reference to its sporadic form. The study presents the mechanisms of action, areas of activity, specificity of functions, as well as ways of regulating the expression of suppressor genes, taking into account their role in colorectal cancer - a role that can shed new light on the diagnostics and therapy of the disease.

\section{RB1 and TP53 genes}

The RB1 gene was the first discovered suppressor gene, and it is classified as a classic suppressor. The RB1 gene, located on 13q14.2, encodes the RB protein, which is a negative regulator of the cell cycle (prevents the cell from S phase entry). RB binds to E2F transcription factors and blocks the transcription of genes necessary for DNA replication (G1 phase arrest) [5-7].

In many cancers, the classic loss of function of the $R B 1$ gene is observed, and thus the reduction or loss of expression of its protein product $[4,8]$. In contrast, an increase in $R B 1$ gene expression was found in both mRNA and protein levels in colorectal cancer tissue. The overexpression of the $R B 1$ gene in cancer cells in $\mathrm{CRC}$ is probably the result of the need to maintain a homeostatic balance between feedback mechanisms that coordinate levels of proteins regulating proliferation and apoptosis. Its role in CRC carcinogenesis is functional transcript and protein regulation rather than the classic role of a suppressor associated with gene inactivation [8].

The TP53 gene located on chromosome 17p13.1 is an important classic suppressor gene that plays an important role in the signal transduction pathway by stopping the cell cycle (using the RB protein) and activating apoptosis. The TP53 gene, called the guardian of the genome, identifies DNA damage. This gene in its wild type form encodes the p53 protein, which acts as a transcription factor for several target genes. The CDKN1A gene, a major transcriptional target of p53, codes for the p21 cyclin-dependent kinase inhibitory protein, which causes cell cycle arrest. MDM2 is another important transcriptional target gene of p53, where the MDM2 protein controls the level of p53 by a negative autoregulatory feedback loop in which MDM2 binds to and ubiquitinates p53, targeting it for proteasomal degradation. The proapoptotic action of the p53 protein is the result of proapoptotic BAX gene activation, antiapoptotic BCL2 gene inhibition, as well as stimulation of cytochrome c to cell caspases activation, which is responsible for final cell degradation $[9,10]$.

Gene mutation can cause continuous cell replication, despite DNA damage as well as damage in programmed cell death activation as an effect of mutant p53 protein action. Mutations in the TP53 gene are the most common genetic changes in cancer, with mutations being present in approximately $50 \%$ of all invasive tumours [11]. Somatic mutations in the TP53 gene are reported in approximately $43.32 \%$ of CRC cases. According to the COSMIC database, more than 50\% of the TP53 alterations are missense mutations. This is followed by non-sense mutations contributing to about $10 \%$ of total TP53 alterations [12, 13]. Mutant p53 protein is an important candidate target against which new anticancer treatments could be developed. Some compounds have recently been reported to reactive mutant p53 protein by converting it to a form exhibiting wild-type properties. Consistent with the reactivation of mutant $\mathrm{p} 53$, these compounds have been shown to exhibit anticancer activity in preclinical models expressing mutant p53. There is a need for further studies to show whether any mutant p53-reactivating compound has efficacy for the treatment of human cancer [11].

In addition to mutations in the TP53 gene, the relationship between various TP53 polymorphisms and the encoded protein expression has been investigated in recent years. The latest reports from Zhang et al. show a relationship between the TP53 rs1042522 polymorphism and p53 protein expression. According to this study, p53 protein expression affected by TP53 polymorphism is associated with the biological behaviour and prognosis of low rectal cancer (CRC phase and the survival time). It is thought that the TP53 rs1042522 polymorphism and p53 protein expression may serve as indicators to predict the biological behaviour and prognosis of LRC in clinical practice [14].

Assessment of the association between the mutational status of TP53 gene and p53 protein expression has become a challenge in recent years in the study 
of new indicators, which may benefit in the selection of the treatment option and prognostication of treatment efficacy in CRC. Manoharan et al. reported in 2020 that the correlation of functional status of p53 and TP53 variants not only provides clues for the aetiology of the tumour formation, but also may have an impact on treatment efficacy [13].

\section{p16 gene}

The $p 16$ gene (also named CDKN2A, INK4A, CDK4I), located on the $9 \mathrm{p} 21.3$ chromosome, is one of the most studied epigenetic markers in CRC. The $p 16$ gene belongs to the suppressor genes due to its function. The p16 gene encodes the 16 protein, which protects cells from increased proliferation by inhibiting cyclin-dependent kinase 4 (CDK4) involved in cell cycle progression (transition from G1 phase to S phase) [15].

Inactivation of $p 16$ as a tumour suppressor gene causes a loss of cellular capacity to block the cell cycle and is widely known in human cancers [16]. It has been proven that the main mechanism leading to the inactivation of the $p 16$ gene is hypermethylation, which is a common phenomenon in colorectal cancer $[17,18]$. Literature data from 2018 indicate that studies on $p 16$ gene methylated regions in relation to the stage of cancer are underway [19]. To date, the association between hypermethylation of $p 16$ gene regions and p16 protein expression has remained controversial, mainly due to inconsistent, incomparable results obtained by methods that test shorter fragments, different $\mathrm{CpG}$ regions, or other gene target sites. According to Ye et al. from 2018, using the LC-MS/MS (liquid chromatography mass spectrography) method covering larger gene fragments (exons 1 and 2 rich in CpG regions), the entire methylation was assessed in the studied regions achieving very satisfactory and consistent results. Methylation levels were evaluated in paired CRC and adjacent normal tissues. As a result of comparative analysis of results of particular pairs, it was found that there is a clear negative correlation between the degree of exon $2 \mathrm{CpG}$ island methylation and, to a lesser extent, exon 1 , and the expression of the p16 gene as well as protein in the examined tumour tissues, compared to the analysed non-cancerous tissues. In addition, a positive correlation between the degree of methylation and the stage of cancer was observed. These data indicate that the studied regions of the $p 16$ gene may become new, more specific CRC diagnostic biomarkers and the target of new therapies [19].

\section{APC gene}

The APC suppressor gene with a chromosomal 5 q22.2 location plays a key role in the carcinogenesis of colorectal cancer. Embryonic mutations of the APC gene have been identified in familial adenomatous polyposis (FAP), a hereditary disease in which hun- dreds of colon polyps develop, leading to colon cancer. Somatic mutations in both APC alleles are also observed in more than $80 \%$ of sporadic, non-hereditary forms of colorectal cancer [5, 20, 21].

The APC gene encodes the APC protein, which plays an important physiological role in regulating the concentration of transcription cofactor - $\beta$-catenin, which is responsible for promoting proliferation and inhibiting cell differentiation and cell migration. The main function of the APC protein is the regulation of the Wnt/ $\beta$-catenin cell signalling pathway by forming with the Axin protein a destructive complex binding $\beta$-catenin to reduce its concentration [22]. If an $A P C$ gene mutation occurs, the abnormal protein product lacks $\beta$-catenin binding capacity. Accumulated free $\beta$-catenin is continuously transported to the cell nucleus, activating genes responsible for cell division, increasing proliferation, and inhibiting differentiation $[20,23]$.

The APC gene contains 21 exons coding 2843 aa. In the central part the APC contains three 15-aa and seven 20 -aa repeats, which form the $\beta$-catenin binding site. Three amino acid repeats containing the socalled SAMP motif (SER-ALA-MET-PRO) in their core are responsible for interactions with the Axin domain. The APC mutation in FAP is usually located near the $5^{\prime}$ end of the sequence coding the first SAMP repeat, causing the falling out of half of the APC C-terminus (where the Axin binding sites are found), and leading to stabilisation of $\beta$-catenin. The loss of this part of the protein also causes the loss of several NES (nuclear export signal) sequences responsible for the distribution of APC between the cell nucleus and the cytoplasm. This may be of fundamental importance for the functioning of APC, which, in addition to inhibiting the import of $\beta$-catenin into the cell nucleus, simultaneously increases its export from the cell nucleus to the cytoplasm. Research to date suggests that APC may also protect $\beta$-catenin against dephosphorylation catalysed by $2 \mathrm{~A}$ protein phosphatase (PP2A). It may also facilitate the removal of phosphorylated $\beta$-catenin from junctions with Axin and thus facilitate its degradation and create space for the new $\beta$-catenin phosphorylation cycle $[24,25]$. In addition, $\beta$-catenin accumulated as a result of APC protein disfunction disturbs the migration of intestinal epithelial cells towards the mucosa surface, where they peel physiologically. Accumulation of undifferentiated cells in intestinal crypts leads to the formation of polyps [26].

\section{ING4 gene}

The ING4 gene (inhibitor of growth family member 4) with chromosomal location 12p13.31, belonging to the ING gene family, is an important suppressor gene encoding the ING4 suppressor protein involved in cell cycle arrest, apoptosis, DNA repair, chromatin modification, and inhibition of cell migration [27]. 
Decreased ING4 expression often occurs in many cancers, including head cancers, squamous cell carcinoma of the neck, hepatocellular carcinoma, gastric adenocarcinoma, lung, breast, and colorectal cancer, and is often correlated with poor prognosis [28]. Chen et al. report that ING4 plays an important role in inhibiting angiogenesis in colorectal cancer [29] The ING4 protein has in its structure a specific PHD (plant homeodomain), which is responsible for binding of the transcription factor Sp1 (specificity protein 1), destabilisation of its expression, transcription activity, and degradation. There is evidence that both Sp1 expression and transcriptional activity are excessively increased in various types of cancers. High Sp1 expression positively correlates with the maintenance of proliferation and inhibition of apoptosis, induction of angiogenesis, invasion, and metastasis and is generally considered a negative prognostic factor [30]. Sp1 activity is regulated by some post-translational modifications, including phosphorylation via cyclindependent kinase 2 (CDK2) and ubiquitination in which the ING4 protein is involved [29]. ING4 inhibits the phosphorylation activity of CDK 2 by inducing the expression of p21 protein leading to destabilisation and ubiquitination of Sp1, thereby silencing the expression of Sp1-regulated pro-angiogenic MMP-2 and COX-2 genes.

Both mRNA and ING4 protein have been shown to be lower in CRC compared to normal colon tissues [31]. Reports from Chen et al. from 2016 showing the anti-angiogenic activity of ING4 in colorectal cancer provide the basis for the conclusion that restoring normal expression of the ING4 suppressor gene may prove to be an innovative strategy in the treatment of metastatic colorectal cancer [29]. Another study published by You et al. in 2018 confirms the suppressor activity of ING4 in CRC and shows miR-650 as a potent ING4 inhibitor in CRC. According to these studies, miR-650 can target ING4 and thereby stimulate CRC progression through the MAPK signalling pathway. The relationship between miR-650 and ING4 described in this study provides a solid basis for developing new therapeutic strategies in CRC by inhibiting miR-650 and thus restoring normal expression of the ING4 suppressor gene [32].

\section{SMAD4 gene}

The SMAD4 gene (SMAD family member 4) located on chromosome 18q21.2, encodes the SMAD4 protein belonging to the SMAD family of proteins. SMAD proteins are a unique group of proteins involved in signal transduction into the cell after activation of the transforming growth factor- $\beta$ (TGF- $\beta$ ) receptors (TGF- $\beta$ R1 or 2 ). TGF- $\beta$ is a highly relevant cytokine, having the ability to control complex biological processes, including processes of cell differentiation, migration and adhesion, angiogenesis, and apoptosis.
The TGF- $\beta$ signalling pathway regulates, by means of signal proteins from the SMAD family, the expression of hundreds of target genes that coordinate growth slowdown (e.g. CDK inhibitors) or inhibition of epithelial cell proliferation (e.g. c-MYC gene). The activity of SMAD proteins inhibiting carcinogenesis has been identified as antiproliferative and proapoptotic [33].

A defect in the conduction signal through SMAD family proteins is a common anomaly in patients with colorectal cancer. During tumour progression, TGF- $\beta$ activity is often inhibited and, resulting in reduced expression or complete absence of SMAD family proteins. The results of previous studies indicate the usefulness of SMAD protein expression assessment as an independent prognostic factor in, among others, pancreatic and colorectal cancer [34].

SMAD4 is a protein necessary to form a complex that transfers signal proteins to the cell nucleus. Silencing of SMAD4 prevents transcription, making the cells resistant to TGF- $\beta$ inhibition. Smad4 is absent or mutated in numerous tumour types, including pancreatic, colon, gastric, and liver cancer, and particularly in digestive system tumours. Therefore, it is thought to function as a tumour suppressor gene. Mutations in SMAD4 were identified in colorectal cancers, and germline mutations are associated with juvenile polyposis - a rare autosomal dominant inherited gastrointestinal cancer predisposition syndrome. According to recent literature, mutations in the SMAD4 suppressor gene affect about $10 \%$ of sporadic colorectal cancers [35]. Studies by Liao et al. show that mutations in the SMAD4 gene, with the most common change in the MH2 domain of the SMAD4 protein, are much more frequently observed in advanced stages with lymph node metastasis, which suggests that they are an unfavourable prognostic factor.

A number of studies have reported that low expression of SMAD4 is associated with EMT and poor prognosis of colon cancer. EMT is thought to play an important role in CRC metastasis as well as in increased drug resistance. According to a study by Lin et al. from 2019, silencing SMAD4 attenuated the sensitivity of SW480 CRC cells to cetuximab by partial reversal of the effects of cetuximab on the mRNA and protein expression levels of vimentin, $\mathrm{Bax} / \mathrm{Bcl}-2$, and E-cadherin, while SMAD4 overexpression enhanced SW480 cell sensitivity to cetuximab. In this study, silencing SMAD4 partly reversed the expression of E-cadherin increased by cetuximab and the expression of vimentin decreased by cetuximab. According to this publication, several previous studies have reported that mutation or loss of SMAD4 in CRC is also closely associated with chemoresistance on conventional chemotherapeutic drugs, including 5-fluorouracil and oxaliplatin. This is evidence that SMAD4 may play a vital role in the sensitivity of CRC cells to chemotherapeutic drugs by promoting EMT [36]. 
It seems important to search for pharmacological factors that restore wild-type SMAD4 function, which could improve current therapy.

Reports from Chung et al. from 2018 show that the loss of the SMAD4 protein together with the PTEN protein has a synergistic effect leading to a more aggressive form of the disease and an unfavourable prognosis in patients with CRC compared to the loss of SMAD4 alone [37].

\section{KLF10 gene}

The KLF10 (Krüppel-like factor) gene, originally called the inducible early gene 1 TGF- $\beta$ (TIEG1 transforming growth factor $\beta$ inducible early gene 1 ), located on chromosome 8q22, encodes the KLF10 protein, which is a DNA binding transcription regulator containing the triple zinc finger domain, one of the structural motifs responsible for binding to DNA. By binding DNA and interacting with other regulatory transcription factors, KLF10 stimulates and suppresses the expression of many genes in many cell types. KLF10 exhibits antiproliferative activity and induces apoptosis in various cancer cells, which has allowed the gene to be described as a tumour suppressor gene. KLF10 is thought to act as a suppressor gene in many types of cancer, including colorectal cancer.

Many studies have shown that the KLF10 gene acts as a tumour suppressor mainly through the TGF- $\beta$ signalling pathway.

As shown in Figure 1, the KLF10 gene expression is induced in a manner dependent on the SMAD2/3/4 protein complex. By affecting TGF- $\beta$-dependent target genes, KLF10 simultaneously inhibits the inhibitory effect of the SMAD7 protein on TGF- $\beta$, thus interfering with the negative feedback loop. In addition, KLF10 serves as a positive feedback loop to regulate TGF- $\beta$ signalling by inducing SMAD2 expression [38].

In colorectal cancer cells, the KLF10 gene is additionally one of the mediators of signal transduction of the peroxisome proliferator activated $\gamma$ receptor (PPAR- $\gamma$ ) pathway. Peroxisome proliferator activated receptors (PPARs) are transcription factors that belong to the family of nuclear hormone receptors. Their main role is to regulate metabolism - regulation of insulin resistance, fatty acid metabolism, and maintenance of glucose homeostasis. They can also affect the regulation of cell survival and proliferation through metabolism.

Colorectal cancer cells contain a high concentration of PPAR- $\gamma$, but its inhibitory function is very low, which means a defect in the PPAR- $\gamma$ pathway. Studies have also shown that 15-hydroxy-eicosatetraenoic acid (15S-HETE), an endogenous ligand for PPAR $\gamma$, is significantly reduced in the serum of patients with colon cancer, and treatment with 15-hydroxy-eicosatetraenoic acid (15S-HETE) stops colon cancer cells from growing through the PPAR $\gamma$-dependent pathway, which is preceded by an increased expression of KLF10 and a decrease in expression of the antiapoptotic BCL-2 (B cell lymphoma 2) gene. 15S-HETE activity may be blocked when PPAR- $\gamma$ is turned off, e. g. as a result of mutation [39].

KLF10 is thought to play an important role in inhibiting cancer cell proliferation and promoting apoptosis, which highlights its suppressor properties. There is still limited information on the KLF10 mechanism in cancer, and additional information is needed to understand its role in diseases, including cancer [38].

\section{PTEN gene}

The PTEN gene (phosphatase and tensin homologue gene) belongs to the suppressor genes, which are some of the most common genetic defect targets in human cancer. It is located on chromosome 10q23.31 and encodes the PTEN protein belonging to the phosphatase group. The PTEN gene is a tumour suppressor that negatively regulates the phosphoinositol-3-kinase/AKT signalling pathway, the function of which is to stimulate growth, cell proliferation, cell cycle progression, and inhibition of apoptosis. The PTEN protein plays a role as the inhibitor of phospha-

\begin{tabular}{|c|c|c|}
\hline Target organ & Target genes & Role \\
\hline Breast & $S M A D 2,3, B R C A 1 / B R A D 1$ & Suppressor \\
\hline Kidney & $V H L, G F-\beta 1$ & Suppressor \\
\hline Liver & $\begin{array}{c}\text { SMAD2, P15, TGF- } \beta \\
\text { SMAD3, SMAD7 }\end{array}$ & $\begin{array}{l}\text { Activator } \\
\text { Suppressor }\end{array}$ \\
\hline Lung & $S M A D / T G F-\beta, S N A 11, H D C A 1$ & Suppressor \\
\hline Pancreas & SMAD2 & Suppressor \\
\hline Prostate & $\begin{array}{c}\text { SMAD dependent } \\
\text { pathway }\end{array}$ & Suppressor \\
\hline
\end{tabular}

Figure 1. Intermediary role of the KLF10 gene in the TGF- $\beta$ signalling pathway for various target tissues 
tidylinositol 3-kinase (PI3K) - the upstream protein of this process. The loss of PTEN protein leads to an uncontrolled course of the AKT kinase signalling pathway and, as a result, to increased cell proliferation and inhibition of apoptosis [36]. PTEN is important in sustaining cell homeostasis and genomic stability, and its inactivation almost always leads to cancer [40].

A feature of colorectal cancers is the relatively low frequency of PTEN mutations or deletions, while a decrease in PTEN occurs in about a third of tumours. Recent reports indicate that PTEN inactivation may be even greater when taking into account the changes in post-translational modifications and/or incorrect location of the gene or suppressor protein, posttranscriptional targeting by microRNAs (miRNAs/miRs), and regulation by transcription factors. They have all been shown to affect the tumour suppressor functions of PTEN. It is suggested that strategies based on pharmacologically induced restoration of wild-type PTEN function in colorectal cancer cells should be considered to inhibit cell growth, induce apoptosis, and sensitise cancer cells to therapeutic agents [41].

The latest studies confirm that the PTEN expression in CRC depends not only on discrete and stepwise changes in PTEN allele loss, as described in the twohit hypothesis. Increasing evidence supports dosagedependency of PTEN tumour suppressor function in CRC connected with the influence of the aforementioned mechanisms as well as novel factors - the functional involvement of competing endogenous RNAs (ceRNAs) in miRNA-dependent and coding-independent regulation of genes. The ceRNAs are thought to act as PTEN derepressors. A new type of dose-sensitive PTEN suppressive function was described in a study by Roquid et al., published in 2019. The study reported and validated DNA methyltransferase $3 \beta$ (DNMT3B) and TET methylcy tosine dioxygenase 3 (TET3) as novel ceRNAs of PTEN as well as their relationship with miR-4465 in HCT116 colorectal cancer cells. miR4465 was identified as a direct negative regulator of all three transcripts, i.e. DNMT3B, TET3, and PTEN via their 3'untranslated regions (3'UTR). Overexpression of DNMT3B or TET3 3'UTR promoted apoptosis and decreased migratory capacity, potentially because of shared miRNA sequestration and subsequent activation of PTEN expression. The findings of the study identified DNMT3B and TET3 as novel ceRNAs of PTEN that may impact its dose-sensitive tumour suppressive function [42].

\section{BMP5 gene}

The BMP5 (bone morphogenetic protein 5) gene, located on chromosome $6 \mathrm{p} 12.1$, encodes a protein that acts as a ligand for the TGF- $\beta$ protein family and plays a role in bone and cartilage development. Polymorphisms of this gene may be associated with osteoarthritis in humans. Different expression of this gene is also observed in many human cancers. The BMP5 gene has already been classified as a suppressor gene in myeloma, adrenocortical carcinoma and breast cancer, but the expression and significance of BMP5 in gastrointestinal cancers have not yet been fully studied. The recent research carried out in China by Chen et al. shows that the nonsense BMP5 mutation is a characteristic change observed in colorectal cancer, and the loss of BMP5 expression is specific and dominant for CRC, which may indicate that it occurs at an early stage of epithelial changes. The level of BMP5 mRNA observed in the experiment was significantly reduced in colorectal tumour tissue compared to normal tissues. In addition, low BMP5 expression correlated with poor patient survival, which was not seen in studies on the remaining six types of cancer. The study revealed that, in addition to the main TGF- $\beta$ / SMAD signalling pathway that inhibits cell growth by arresting the cell cycle [43], BMP5 induces cell cycle arrest by stimulating the expression of CDKN1 - a strong binding inhibitor of several cyclin/CDK G1 complexes and a negative regulator of cell proliferation leading to cell cycle phase arrest at the G1-S level. In addition, transcriptome sequencing studies have discovered a novel cell growth inhibition pathway that BMP5 transduces through the JAK/STAT signalling pathway by playing the role of a negative regulator in this path [44]. The JAK (Janus-activated-kinase)/ STAT (signal transducer and activator of transcription) pathway transmits signals from cytokines, interleukins, and growth factors through transmembrane receptors to cytoplasm and finally to the nucleus, modulating the transcription of genes that control cellular proliferation, differentiation, and apoptosis [45].

The co-expression analysis of the EPSTI1 core gene carried out in the Chen et al. study showed a relationship between BMP5 and the JAK-STAT pathway and proved the role of BMP5 in CRC initiation. The EPSTI1 gene induces stromal fibroblasts and shows strong overexpression in cancerous tissues in breast cancer [46]. EPSTI1 expression levels are associated with tumour initiation, stem cell properties, and epithelial-mesenchymal transformation (EMT). Increased levels of EPSTI1 are involved in the activation of the JAK-STAT pathway induced by IL28A (interleukin 28A), and BMP5 negatively suppresses IL28A expression, thereby inhibiting genes downstream in the pathway. In addition, in the part of the experiment carried out on the HT-29 cell line, it was shown that cells expressing BMP5 had an increased level of epithelial markers CK13, CK19, and E-cadherin and a decrease in the level of mesenchymal markers such as chemokines MMPs or CCL, compared to non-BMP5 expressing cells. This is evidence of a relationship between BMP5 expression and inhibition of the epithelial-mesenchymal transition (EMT), a phenomenon responsible for tumour progression [44]. 
Suppressive BMP5 function was confirmed in another recent report by Chen et al., the results of which suggested a significant role of the miR-32/BMP5 axis in CRC tumorigenesis. The bioinformatic analyses conducted in the study identified that miR-32 expression is associated with CRC lymphatic invasion and metastasis, and correlates with poor patient survival, and revealed that BMP5 protein is a direct target of miR-32. The loss of tumour suppressor BMP5 may partially due to the miR-32 dysregulation. The functional assays confirmed the miR-32/BMP5 oncogenic-suppressive correlation and demonstrated that overexpression of miR-32 in LoVo cells promoted cell proliferation and migration, whereas inhibition of miR-32 in HCT 116 cells showed the contrary results. The inverse correlation between miR-32 and BMP5 was observed in CRC, especially in advanced tumour patients. Furthermore, cotransfection of miR-32 mimics and BMP5 recombinant vector in LoVo cells showed that BMP5 could reverse the oncomiR effect of miR-32 [47].

The discovery of common mutations in BMP5, mechanisms of its regulation, together with data indicating its effect on cell growth and migration, as well as the ability of suppression the oncomiR-32, suggest that BMP5 is an important suppressor gene in colorectal cancer. It should be emphasised that the loss of BMP5 occurs at an early stage of CRC, and its prognostic value and pattern of co-expression with E-cadherin may be specific, especially for sporadic colorectal cancer. In view of the above, BMP5 appears to be a new suppressor gene that can affect initiation, progression, and prognosis in colorectal cancer.

It is worth emphasising that all previous reports, together with those mentioned above, about the role of BMP5 in CRC have been confirmed in the latest multibioinformatic analysis from 2019 done by Adnan Karim et al. According to this report, BMP5 meets the conditions for becoming a new biomarker and a potential therapeutic target for various human cancers, including CRC [48].

\section{FLYWCH1 gene}

The FLYWCH1 gene with chromosomal location $16 \mathrm{p} 13.3$ belongs to the genes encoding the FLYWCH1 protein containing the zinc finger motif domain, acting as a DNA binding agent in the Wnt/ $\beta$-catenin signalling pathway. The Wnt signalling pathway with its main $\beta$-catenin transmitter plays a key role in the development of cancerous colon tissue. The negative regulator of $\beta$-catenin, and thus the Wnt pathway in colorectal cancer, is the well-known APC protein described above; however, it is known that inactivation of $\beta$-catenin also occurs under the influence of other molecular interactions. Last year, a British-American research group reported a new Wnt pathway transcription modulator - FLYWCH1 [49]. Muhammad et al. demonstrated that FLYWCH1 binds to non-phosphorylated (nuclear) $\beta$-catenin, preventing its attachment by TCF4 (T-cell factor 4 ) and effectively inhibits the transcriptional activity of the Wnt/ $\beta$-catenin pathway by competing with TCF4 for binding to $\beta$-catenin. FLYWCH1, by transforming the transcriptional activity of $\beta$-catenin/TCF4, selectively regulates the expression of specific genes associated with migration and cell morphology, such as ZEB1 (zinc finger E-box binding homeobox 1), EPHA4 (ephrin typeA receptor 4), and E-cadherin. ZEB1 and EPHA4 are associated with polarisation and cell migration during the development of colorectal cancer and metastasis, and E-cadherin is responsible for cell adhesion. Changes in cell motility and morphology are the initial steps towards invasion and metastasis, one of the most important cancer characteristics. Overexpression of FLYWCH1 has been shown to reduce motility and increase cell adhesion. The study revealed a new molecular mechanism in which FLYWCH1 plays the role of a tumour suppressor. The FLYWCH1/ $\beta$-catenin complex represses the selectively targeted genes of the Wnt pathway, including the $\beta$-catenin-induced ZEB1 gene, thereby increasing cadherin-mediated cell binding and, as a result, preventing colorectal cancer metastasis. It is suggested that FLYWCH1 may become a potential biomarker and therapeutic target against metastatic colorectal cancer in the future.

\section{SARDH gene}

The SARDH (sarcosine dehydrogenase) gene is a gene located on chromosome $9 q 34.2$ encoding the enzyme protein sarcosine dehydrogenase, which catalyses the reaction of oxidative demethylation of sarcosine in the mitochondrial matrix. In a study at the University of Xi'an [50], a $S A R D H$ gene mutation was found in sporadic colorectal cancer (sCRC). SARDH was abnormally lowered in SCRC at both transcriptional and translational levels. It was observed that overexpression of $S A R D H$ inhibited the proliferation, migration, and invasion of colon cancer cell lines, while silencing it stimulated these processes. $S A R D H$ mRNA levels were also reduced in oesophageal cancer, lung cancer, liver cancer, and pancreatic cancer. $S A R D H$ has been identified as a new suppressor gene. Sporadic colorectal cancer is a highly heterogeneous complex disease. Classic markers for sCRC, including mutations in the APC, KRAS, BRAF, and TP53 genes and epigenetic changes can only identify some cases of this condition, so new biomarkers are being sought. In this context, $S A R D H$ appears as a new marker for sCRC that may become a therapeutic target in the future.

\section{TUSC7 gene}

The TUSC7 gene (tumour suppressor candidate 7), belongs to the group of long noncoding RNAs 
(lncRNAs) and is located on chromosome 3q13.31. It joined the class of new suppressor genes showing a reduction in expression in cell lines and tissues of colorectal cancer. According to Ren et al. from 2017, the decrease in expression correlates with the stage of the disease and the overall survival rate [51]. In the above study, lower TUSC7 expression was observed in patients with high-grade colorectal cancer (according to Dukes' classification: C and D) compared to patients with low-grade colorectal cancer (Dukes' classification: A and B). A group of patients with colorectal cancer with lower TUSC7 expression had worse overall survival rates. Further literature data from 2017 confirm the relationship between silencing TUSC7 expression and lower survival rates [52]. Increased expression of TUSC7 has also been found to inhibit proliferation of colon cancer cells of the SW480, HT29, HCT116 and CaCo-2 cell lines [51-53]. In addition, studies show that TUSC7 overexpression by negatively regulating miR-10a expression increased expression of the PTEN gene that encodes the PTEN protein, which is a negative regulator of the AKT signalling pathway, an inhibitor of cell proliferation and cell cycle progression. The PTEN gene was the direct target of miR-10a. The results suggest that the TUSC7 suppressor gene may be a new therapeutic target in colorectal cancer due to the possibility of miR-10a inhibition [51].

\section{RASSF6 gene}

The RASSF6 gene (Ras-association domain family member 6) with chromosomal location 4q13.3 belongs to the family of RASSF suppressor genes acting as mediators in the biochemical Hippo signalling pathway. Scientific reports confirm the extremely important role of the components of this pathway in the process of tumorigenesis in various types of tissues [54].

The main components of the pathway are kinases MST1 and 2 (mammalian STE20-like kinases 1 and 2) and LATS1 and 2 (large tumour suppressor kinases 1 and 2), whose cascade action is to inhibit the function of its nuclear effector - the YAP protein (Yes-associated protein1) as a transcription co-activator. The RASSF6 gene acts as a parent element regulating the aforementioned pathway kinases. During genetic studies on the main components of the Hippo pathway, parent elements were included in the group of genes regulating cell proliferation. It has also been shown that mutations within them often cause uncontrolled growth and increased cell proliferation [55].

Hippo pathway inactivation due to disturbances in the expression of one of the parent elements activates YAP protein, which meets all the conditions necessary to initiate the process of cancer transformation [56]. It turns out that in most cases disorders of the Hippo pathway inhibit its suppressive activity relative to the YAP transcriptional co-activator, which en- hances cell proliferation and avoidance of cell apoptosis. Decreased expression of the genes encoding MST1/2, LATS1, and LATS2 was found in gastrointestinal cancers, including gastric cancer (MST1/2, LATS1) as well as in hepatocellular carcinoma and bile duct cancer (LATS2) [55].

Proteins from the RASSF family are involved in the activation of Hippo pathway kinases, basic proapoptotic kinases - MST1 (RASSF2 protein) and MST2 (RASSF1 protein) [55]. Reports by Iwasa et al. from 2015 [57] and Chen et al. from 2016 [58] show that also RASSF6 interacting with MST kinases is one of the parent elements of the Hippo signalling pathway. Moreover, the studies of both of the abovementioned teams show that RASSF6 regulates apoptosis and the cell cycle by binding to the MDM2 gene (TP53 gene inhibitor) causing degradation of the MDM2 protein and thereby regulating p53 protein expression $[57,58]$. The research by Chen et al. has shown that increased expression of RASSF6 induces apoptosis in the mechanism of activation of the proapoptotic $B A X$ gene and induction of cytochrome $\mathrm{c}$ release, which activates caspases in the cell responsible for its final degradation [58]. This means that RASSF6 induces apoptosis in the caspase-dependent pathway, as well as in the Hippo pathway - acting independently. In addition, a 2016 Chen et al. study reported the detection of loss of function mutation and the RASSF6 gene missense in patients with sporadic colorectal cancer. Reduced RASSF6 levels were observed in adenocarcinoma cells compared to normal tissue cells in the cases studied. Gene expression inhibition occurs by hypermethylation, but other regulatory mechanisms are also contemplated. In the above-mentioned study, RASSF6 implementation suppressed proliferation, migration, and invasion as well as induction of in vitro apoptosis of LoVo colorectal cancer cells and inhibited tumour growth in vivo. On the other hand, silencing of RASSF6 in HT29 cells showed the opposite effect [58].

Another study, reported by Zhou et al. in 2017, revealed that low RASSF6 expression corresponds to a poor prognosis in colorectal cancer patients, and low RASSF6 expression is markedly associated with tumour progression. An investigation of in vitro CRC cell lines (DLD1 and HCT116) confirmed the suppressive role of RASSF6 and provided the information that RASSF6 inhibits the expression of the classical target genes of Wnt signalling as demonstrated by the reduced expression of TCF1, c-Jun, and c-Myc in RASSF6-overexpressing DLD1 stable cell lines. Moreover, the research showed the correlation of RASSF6 downregulation with EMT promotion. The expression levels of the epithelial markers ZO-1 and E-cadherin were increased, while the expression level of the mesenchymal marker Snail was decreased in an RASSF6-overexpressing DLD1 cell line. Exploring the molecular mechanism of colorectal cancer metastasis 
is important due to the fact that distant metastasis is the primary barrier for the successful treatment of patients with colorectal cancer [59].

The above reports show that the RASSF6 gene functions as a suppressor gene in CRC, and the conducted experiments prove that it can be used in targeted therapy of the sporadic forms of colorectal cancer.

\section{Summary}

This review presents current knowledge about the molecular mechanisms regulating the expression, activity, and function of suppressor genes, which were silenced in colorectal cancer tissues and cell lines, and restoration of their correct expression inhibited proliferation and invasion of CRC cells. The mechanisms of biochemical pathway action presented in this review, in which the genes responsible for regulating cell proliferation and apoptosis are involved, demonstrates the complexity of the process in which the cell determines its purpose. Each element of a given signal pathway individually, but also interacting with other proteins, has its unique function in the cell cycle. Disturbances of action, mainly due to the changed level of expression, cause many modifications that can initiate the process of neoplastic transformation. It is significant that despite the large amount of information obtained on the functioning of the presented pathways and their individual components, new aspects are constantly emerging in which these pathways can potentially perform superior regulatory functions, and the complex network of connections between biochemical pathways is still not fully understood. The use of the potential of individual elements of a given pathway in targeted cancer therapy will be possible only after a more accurate description of their regulation disorders in states of uncontrolled cell growth and division. In the case of sCRC, which accounts for about $80 \%$ of colorectal cancer cases, the spectrum of somatic mutations contributing to gene expression disorders and the proteins they encode is not fully understood compared to, e.g. hereditary non-polyposis colorectal cancer (HNPCC). In light of modern scientific reports, it is known that sCRC genetic changes include not only APC gene mutations at an early stage of adenomatous polyp development, activation of the KRAS oncogene from early adenoma to late adenoma, or suppression of suppressor genes such as p53, but also many mutations and epigenetic changes of other genes, whose brief characteristics are described above. The dynamic development of modern molecular technologies makes it possible to screen the entire genome for new candidate genes whose identification is key to understanding the spectrum of genetic mutations in sCRC. Understanding the changes in the expression profile of suppressor genes in tumour induction and progression can be important for personalising colorectal cancer treatment and can also be the basis for developing new molecularly targeted therapeutic strategies.

\section{Acknowledgments}

This study was supported under the program of the Minister of Science and Higher Education under the name Regional Initiative of Excellence in 20192022 project number: 024/RID/2018/19, financing amount: 11,999,000.00 PLN.

\section{Conflict of interest}

The authors declare no conflict of interest.

\section{References}

1. McFerran E, O'mahony JF, Fallis R, Mcvicar D, Zauber AG, Kee F. Evaluation of the effectiveness and cost-effectiveness of personalized surveillance after colorectal adenomatous polypectomy. Epidemiol Rev 2017; 39: 148-160.

2. Rawla P, Sunkara T, Barsouk A. Epidemiology of colorectal cancer: incidence, mortality, survival, and risk factors. Prz Gastroenterol 2019; 14: 89-103.

3. www.onkologia.org.pl. Krajowy Rejestr Nowotworów.

4. Tobias ES, Connor M, Ferguson-Smith M. Medical Genetics. Wiley-Blackwell 2014.

5. Sherr CJ. Principles of tumor suppression. Cell 2004; 116: 235-246.

6. Nevins JR. The Rb/E2F pathway and cancer. Hum Mol Genet 2001; 10: 699-703.

7. Trimarchi JM, Lees JA. Sibling rivalry in the E2F family. Nat Rev Mol Cell Biol 2002; 3: 11-20.

8. Lai PS, Cheah PY, Kadam P, Chua CLM, Lie DKH, Li HH, Eu KW, Seow-Choen F, Lee AS. Overexpression of RB1 transcript is significantly correlated with 13q14 allelic imbalance in colorectal carcinomas. Int J Cancer 2006; 119: 1061-1066.

9. Kopczyński P, Krawczyński MR. The role of oncogenes and tumor suppressor genes in oncogenesis. Now Lek 2012; 81: 679-681.

10. Slattery ML, Mullany LE, Wolff RK, Sakoda LC, Samowitz WS, Herrick JS. The p53-signaling pathway and colorectal cancer: interactions between downstream p53 target genes and miRNAs. Genomics 2019; 111: 762-771.

11. Duffy MJ, Synnott NC, Crown J. Mutant p53 as a target for cancer treatment. Eur J Cancer 2017; 83: 258-265.

12. Tate JG, Bamford S, Jubb HC, Sondka Z, Beare DM, Bindal N, Boutselakis H, Cole CG, Creatore C, Dawson E, Fish P, Harsha B, Hathaway C, Jupe SC, Kok CY, Noble K, Ponting L, Ramshaw CC, Rye CE, Speedy HE, Stefancsik R, Thompson SL, Wang S, Ward S, Campbell PJ, Forbes SA. COSMIC: the catalogue of somatic mutations in cancer. Nucleic Acids Res 2019; 47: D941-D947.

13. Manoharan V, Karunanayake EH, Tennekoon KH, De Silva S, Imthikab AIA, De Silva K, Angunawela P, Vishwakula S, Lunec J. Pattern of nucleotide variants of TP53 and their correlation with the expression of p53 and its downstream proteins in a Sri Lankan cohort of breast and colorectal cancer patients. BMC Cancer 2020; 20: 72.

14. Zhang G, Xu Q, Wang Z, Sun L, Lv Z, Liu J, Xing C, Yuan Y. P53 protein expression affected by TP53 polymorphism is associated with the biological behavior and prognosis of low rectal cancer. Oncol Lett 2019; 18: 6807-6821. 
15. Serrano M, Hannon GJ, Beach D. A new regulatory motif in cell-cycle control causing specific inhibition of cyclin D/CDK4. Nature 1993; 366: 704-707.

16. Zhao R, Choi BY, Lee M-H, Bode AM, Dong Z. Implications of genetic and epigenetic alterations of CDKN2A (p16 INK4a) in cancer. EBioMedicine 2016; 8: 30-39.

17. Mitomi H, Fukui N, Tanaka N, Kanazawa H, Saito T, Matsuoka T, Yao T. Aberrant p16INK4a methylation is a frequent event in colorectal cancers: prognostic value and relation to mRNA expression and immunoreactivity. J Cancer Res Clin Oncol 2010; 136: 323-331.

18. Barault L, Charon-Barra C, Jooste V, De La Vega MF, Martin L, Roignot P, Rat P, Bouvier AM, Laurent-Puig P, Faivre J, Chapusot C, Piard F. Hypermethylator phenotype in sporadic colon cancer: study on a population-based series of 582 cases. Cancer Res 2008; 68: 8541-8546.

19. Ye X, Mo M, Xu S, Yang Q, Wu M, Zhang J, Chen B, Li J, Zhong Y, Huang Q, Cai C. The hypermethylation of p16 gene exon 1 and exon 2: Potential biomarkers for colorectal cancer and are associated with cancer pathological staging 11 Medical and Health Sciences 1112 Oncology and Carcinogenesis. BMC Cancer 2018; 18: 1023.

20. Aghabozorgi AS, Bahreyni A, Soleimani A, Bahrami A, Khazaei M, Ferns GA, Avan A, Hassanian SM. Role of APC gene mutations in the pathogenesis of colorectal cancer current status and perspectives.pdf. Biochimie 2019; 157: 64-71.

21. Zhang M, Yang D, Gold B. The Adenomatous Polyposis Coli (APC) mutation spectra in different anatomical regions of the large intestine in colorectal cancer. Mutat Res 2018; 810: 1-5.

22. Reya T, Clevers H. Wnt signalling in stem cells and cancer. Nature 2005; 434: 843-850.

23. Tanneberger K, Pfister AS, Kriz V, Bryja V, Schambony A, Behrens J. Structural and functional characterization of the Wnt inhibitor APC membrane recruitment 1 (Amer1). J Biol Chem 2011; 286: 19204-19214.

24. Rogacki K. Rola komórkowej ekspresji beta-kateniny i E-kadheryny jako markerów progresji zmian w przewlekłym zapaleniu wątroby typu C. Rozprawa na stopień doktora nauk medycznych. Uniwersytet Medyczny im. K. Marcinkowskiego w Poznaniu 2014.

25. Hankey W, Frankel WL, Groden J. Functions of the APC tumor suppressor protein dependent and independent of canonical WNT signaling: implications for therapeutic targeting. Cancer Metastasis Rev 2018; 37: 159-172.

26. Brembeck FH, Rosário M, Birchmeier W. Balancing cell adhesion and Wnt signaling, the key role of beta-catenin. Curr Opin Genet Dev 2006; 16: 51-59.

27. Yan R, He L, Li Z, Han X, Liang J, Si W, Chen Z, Li L, Xie G, Li W, Wang P, Lei L, Zhang H, Pei F, Cao D, Sun L, Shang Y. SCFJFK is a bona fide e3 ligase for ING4 and a potent promoter of the angiogenesis and metastasis of breast cancer. Genes Dev 2015; 29: 672-685.

28. Cui S, Gao Y, Zhang K, Chen J, Wang R, Chen L. The emerging role of inhibitor of growth 4 as a tumor suppressor in multiple human cancers. Cell Physiol Biochem 2015; 36: 409-422.

29. Chen Y, Huang Y, Hou P, Zhang Z, Zhang Y, Wang W, Sun G, Xu L, Zhou J, Bai J, Zheng J. ING4 suppresses tumor angiogenesis and functions as a prognostic marker in human colorectal cancer. Oncotarget 2016; 7: 79017-79031.

30. Vizcaíno C, Mansilla S, Portugal J. Sp1 transcription factor: a long-standing target in cancer chemotherapy. Pharmacol Ther 2015; 152: 111-124.
31. You Q, Wang X, Fu S, Jin X. Downregulated expression of inhibitor of growth 4 (ING4) in advanced colorectal cancers: a non-randomized experimental study. Pathol Oncol Res 2011; 17: 473-477.

32. You Q, Li H, Liu Y, Xu Y, Miao S, Yao G, Xue Y, Geng J, Jin $\mathrm{X}$, Meng $\mathrm{H}$. MicroRNA-650 targets inhibitor of growth 4 to promote colorectal cancer progression via mitogen activated protein kinase signaling. Oncol Lett 2018; 16: 2326-2334.

33. Zhao M, Mishra L, Deng CX. The role of TGF-beta/SMAD4 signaling in cancer. Int J Biol Sci 2018; 14: 111-123.

34. Witkowska M, Smolewski P. Białka z rodziny SMAD: współczesna wiedza na temat ich ekspresji i potencjalnej roli w chorobach nowotworowych. Postep Hig Med Dosw 2014; 68: 301-309.

35. Liao X, Hao Y, Zhang X, Ward S, Houldsworth J, Polydorides AD, Harpaz N. Clinicopathological characterization of SMAD4-mutated intestinal adenocarcinomas: a case-control study. PLoS One 2019; 14: e0212142.

36. Lin Z, Zhang L, Zhou J, Zheng J. Silencing Smad4 attenuates sensitivity of colorectal cancer cells to cetuximab by promoting epithelial-mesenchymal transition. Mol Med Rep 2019; 20: 3735-3745.

37. Chung Y, Wi YC, Kim Y, Bang SS, Yang JH, Jang K, Min KW, Paik SS. The Smad4/PTEN expression pattern predicts clinical outcomes in colorectal adenocarcinoma. J Pathol Transl Med 2018; 52: 37-44.

38. Memon A, Lee WK. KLF10 as a tumor suppressor gene and its TGF-beta signaling. Cancers 2018; 10: 161.

39. Chen GG, Xu H, Lee JFY, Subramaniam M, Leung KL, Wang SH, Chan UP, Spelsberg TC. 15-hydroxy-eicosatetraenoic acid arrests growth of colorectal cancer cellsvia a peroxisome proliferator-activated receptor gamma-dependent pathway. Int J Cancer 2003; 107: 837-843.

40. Roock W De, Vriendt V De, Normanno N, Ciardiello F, Tejpar S. KRAS, BRAF, PIK3CA, and PTEN mutations: implications for targeted therapies in metastatic colorectal cancer. Lancet Oncol 2011; 12: 594-603.

41. Kotelevets L, Scott MGH, Chastre E. Targeting PTEN in colorectal cancers. Adv Exp Med Biol 2018; 1110: 55-73.

42. Roquid KAR, Alcantara KMM, Garcia RL. Identification and validation of mRNA 3'untranslated regions of DNMT3B and TET3 as novel competing endogenous RNAs of the tumor suppressor PTEN. Int J Oncol 2020; 56: 544-558.

43. Ye L, Jiang WG. Bone morphogenetic proteins in tumour associated angiogenesis and implication in cancer therapies. Cancer Lett 2016; 380: 586-597.

44. Chen E, Yang F, He H, Li Q, Zhang W, Xing J, Zhu Z, Jiang J, Wang H, Zhao X, Liu R, Lei L, Dong J, Pei Y, Yang Y, Pan J, Zhang P, Liu S, Du L, Zeng Y, Yang J. Alteration of tumor suppressor BMP5 in sporadic colorectal cancer: a genomic and transcriptomic profiling based study. Mol Cancer 2018; 17: 176.

45. Thomas SJ, Snowden JA, Zeidler MP, Danson SJ. The role of JAK/STAT signalling in the pathogenesis, prognosis and treatment of solid tumours. Br J Cancer 2015; 113: 365-371.

46. De Neergaard M, Kim J, Villadsen R, Fridriksdottir AJ, Rank F, Timmermans-Wielenga V, Langerød A, BørresenDale AL, Petersen OW, Rønnov-Jessen L.Epithelial-stromal interaction 1 (EPSTI1) substitutes for peritumoral fibroblasts in the tumor microenvironment. Am J Pathol 2010; 176: 1229-1240.

47. Chen E, Li Q, Wang H, Zhang P, Zhao X, Yang F, Yang J. MiR-32 promotes tumorigenesis of colorectal cancer by 
targeting BMP5. Biomed Pharmacother 2018; 106: 10461051.

48. Adnan Karim M, Samad A, Kumar Adhikari U, Ashraful Kader M, Kabir M, Aminul Islam M. A Multi-omics analysis of bone morphogenetic protein 5 (BMP5) mRNA expression and clinical prognostic outcomes in different cancers using 4 bioinformatics approaches 5. Int J Mol Sci [Internet] 2019; 20. Available from: www.mdpi.com/journal/ijms

49. Muhammad BA, Almozyan S, Babaei-Jadidi R, Onyido EK, Saadeddin A, Kashfi SH, Spencer-Dene B, Ilyas M, Lourdusamy A, Behrens A, Nateri AS. FLYWCH1, a novel suppressor of nuclear beta-catenin, regulates migration and morphology in colorectal cancer. Mol Cancer Res 2018; 16: 1977-1990.

50. He H, Chen E, Lei L, Yan B, Zhao X, Zhu Z, Li Q, Zhang P, Zhang W, Xing J, Du L, Dong J, Yang J. Alteration of the tumor suppressor SARDH in sporadic colorectal cancer: a functional and transcriptome profiling-based study. Mol Carcinog 2019; 58: 957-966.

51. Ren W, Chen S, Liu G, Wang X, Ye H, Xi Y. TUSC7 acts as a tumor suppressor in colorectal cancer. Am J Transl Res 2017; 9: 4026-4035.

52. Xu J, Zhang R, Zhao J. The novel long noncoding RNA TUSC7 inhibits proliferation by sponging MiR-211 in colorectal cancer. Cell Physiol Biochem 2017; 41: 635-644.

53. Zhang H, Song Y, Yang C, Wu X. Overexpression of lncRNA TUSC7 reduces cell migration and invasion in colorectal cancer. Oncol Rep 2019; 41: 3386-3392.

54. Mauviel A, Nallet-Staub F, Varelas X. Integrating developmental signals: a Hippo in the (path)way. Oncogene 2012; 31: 1743-1756.

55. Rybarczyk A, Wierzbicki P, Kowalczyk A, Kmieć Z. Role of the Hippo pathway in cell proliferation and organ size control. Disorders of the pathway in cancer diseases. Postepy Hig Med Dosw 2014; 68: 504-516.

56. Steinhardt AA, Gayyed MF, Klein AP, Dong J, Maitra A, Pan D, Montgomery EA, Anders RA. Expression of Yes-associated protein in common solid tumors. Hum Pathol 2008; 39: 1582-1589.

57. Iwasa H, Jiang X, Hata Y. RASSF6: the putative tumor suppressor of the RASSF family. Cancers (Basel) 2015; 7: 24152426.

58. Chen E, Yang F, He H, Lei L, Liu R, Du L, Dong J, Wang M, Yang J. Decreased level of RASSF6 in sporadic colorectal cancer and its anti-tumor effects both in vitro and in vivo. Oncotarget 2016; 7: 19813-19823.

59. Zhou R, Qiu L, Liu X, Ling L, Li N, Zhou K, Sun J, Yan J, Tan C, Huang X, Han L, Yin L, Xiao G, Liu L. RASSF6 downregulation promotes the epithelial-mesenchymal transition and predicts poor prognosis in colorectal cancer. Oncotarget 2017; 8: 55162-55175.

\section{Address for correspondence:}

Agnieszka M. Piechowska MSc

Department of Surgical Medicine with Medical Genetics Laboratory Institute of Medical Sciences Jan Kochanowski University al. IX Wieków Kielc 19A, Kielce, Poland E-mail: apiechowska@ujk.edu.pl 